\title{
原著
}

\section{胸腺依存性 $\mathrm{C} \mathrm{D} 4^{+} 8^{+}$小腸上皮間リンパ球の 存在とその性状について}

\author{
長 澤 敏 行 \\ 東宗矤科蔽科大学蔽学部蔽科保存学第 2 講座（主任・指噵：不川 烈教授） \\ 東京大学医学部免疫学教室（指導：多田富雄教授）
}

（1991年12月20日 受付）

\section{Presence of Thymus-dependent $\mathrm{CD} 4^{+} 8^{+}$Intestinal Intraepithelial \\ Lymphocytes and Their Characteristics in Mice}

\author{
Toshiyuki Nagasawa \\ Department of Periodontology, Faculty of Dentistry, \\ Tokyo Medical and Dental University \\ (Chief and Director : Prof. Isao Ishikawa) \\ Department of Immunology, Faculty of Medicine, Tokyo University \\ (Director : Prof. Tomio Tada)
}

The purpose of this study was the investigation of the $T$ cell subsets in the gut-associated lymphoid tissues. $\mathrm{CD}^{+} 8^{+} \mathrm{T}$ cells were found to appear temporarily in Peyer's patches of mice at 2 to 3 weeks after birth. They disappeared within a short period of time from Peyer's patches, but constantly populated in the intestinal intraepithelial lymphocytes (iIEL). Three to $10 \%$ of iIEL were $\mathrm{CD}^{+} 8^{+}$in the specific pathogen-free $(\mathrm{SPF})$ condition throughout life. They are mature $\mathrm{T}$ cells with a high density of $\mathrm{CD} 3$ and $\mathrm{TcR} \alpha \beta$ and found to respond to immobilized anti-CD3 antibody. The appearance of $\mathrm{CD} 4^{+} 8^{+} \mathrm{T}$ cells in ilEL was found to be dependent on the thymic selection, since they were absent in the athymic nu/nu mice, and the $\mathrm{V} \beta$ gene usage was dictated by the pattern of thymic selection. $\mathrm{CD} 4^{+} 8^{+} \mathrm{T}$ cells were not found in the germ-free mice but increased in the SPF old mice. These results indicate that the IIEL contain a unique subset of thymus-derived mature $\mathrm{CD} 4^{+} 8^{+} \mathrm{T}$ cells. These cells may repopulate after the thymic selection in the intestine and increase in response to the intestinal microenvironments.

\section{I. 緒言}

免疫反応において中心的役割を担ら T細胞は胸 腺で分化しね梢のリンパ装置に移動する。近年胸 腺にしか存在しないと考兄られていた $\mathrm{CD} 4+8^{+}$ (Double Positive；DP) T細胞が小腸上皮間に存
在することが報告され ${ }^{1,2)}$ ，消化管に 付属した免 疫系に分布するT細胞の特殊性が注目されるよう になった。

本研究は齿周組織に打ける局所の免疫反応を考 えるための基碟として，粘膜免疫の主役を担う消 化管の T 細胞の特殊性を明らかにするために行っ 
た。マウスの小腸の $\mathrm{T}$ 細胞を用いてその分化と機 能，およびその老化に伴ら変化について検索した ものである。

\section{II . 材料および方法}

\section{1. マウス}

SPF (Specific pathogen-free) 下で生育した $\mathrm{BALB} / \mathrm{c}, \mathrm{BALB} / \mathrm{c}$ nude, $\mathrm{C} 3 \mathrm{H} / \mathrm{HeN}, \mathrm{B} 10 . \mathrm{BR}$, B10. A， A/J マウスを用いた。特に指定したも の以外では 8 週齢から 20 週齢のマウスを使用 した。C3H の無菌マウス (Germ Free Mouse ; GF）は理化学研究所より供与を受けた。無菌、 ウスは Trexler-Type vinyl isolator で $50 \mathrm{kGy}$ の 線滅菌した飼料を与えて飼育されたものであ る。

\section{2. リンパ球の分離}

脾蔵，パイエル板などのリンパ球は，組織切除 した $2 \%$ ウシ胎児血清 (Fetal Calf Serum : FCS) を含む Eagle の minimum essential medium (MEM) の中で，通法どおりにスライドグラスに 組織をそっと押し付けることによって細胞を浮遊 させた。小腸上皮間リンパ球 (Intestinal Intraepithelial Lymphocytes ; iIEL) の分離は田ロら の方法3)に従って行った。すなわち，上皮間リン ハ球を分離するために（実験にあたっては，2～ 3 匹のマウスから小腸を同時に採取した）採取し た小腸からパイエル板を切除して綎断し，さらに 5〜10 mm に細切して 2\% FCS 添加 MEM で洗 浄した。この組織を $2 \%$ FCS 添加 RPMI1640 培 地にいれ， $37^{\circ} \mathrm{C} て ゙ 30$ 分静かに振とうした後，15秒 間強く振とうして細胞を含む上清を採取した。集 めた細胞はただちに， $600 \mathrm{mg}$ のナイロンウール を緩く詰めた $20 \mathrm{~m} l$ のシリンジに通して上皮細 胞の塊を除いた。遠心して上清除去後，40\%の Percoll 液 (Sigma, USA) を細胞のペレットに加 えさらに $600 \mathrm{~g}$ で20分遠心し，上清を除去してリ ンパ球を得た。

\section{3. 抗 体}

抗マウスモノクローナル抗体 Thy1.2（クロー ソ $30 \mathrm{H} 12)^{4)}, \mathrm{CD} 3$ (クローン 145-2C11) ${ }^{5}$ ), CD4
(クローン $\left.\mathrm{GK} 1.5)^{6}\right), \mathrm{CD} 8$ (クローン 53-6-72) ${ }^{4}$ ), T細胞レセプター $\alpha \beta$ 鎖 (T cell Receptor $\alpha \beta$ : $\left.\mathrm{T}(\mathrm{R} \alpha \beta) \quad(\text { クローン } \mathrm{H} 57-597)^{7}\right) ， \mathrm{~V} \beta 3$ (クロー

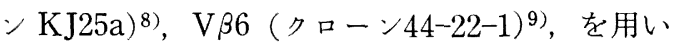
た。

これらの抗体は，ハイブリドーマを含む腹水あ るいは培養上清から，40\%飽和硫安あるいはProtein A (Pharmacia LKB, Biotechnology AB, Uppsala, Sweden) や抗アフィニティーカラムを用いて精製した。

\section{4. フローサイトメトリー解析のための試薬調製}

テキサスレッド標識ストレブトアビジン（TRSA) は BRL 社 (Gaither sburg, Md, USA) か ら購入した。抗 Thy1.2, 抗 CD3, 抗 CD8, 抗 $\mathrm{TcR} \alpha \beta$, 抗 $\mathrm{V} \beta 3$, 抗 $\mathrm{V} \beta 6$ モノクローナル抗体 はアルカリ条件下で fluorescein isothiocyanate (FITC) (BBL Microbioiogy System, Cockeysville, MD) で直接標識した。

抗 CD4 抗体は Hardy らの方法 ${ }^{10)} に$ 従い allophycocyanin (APC, Sigma) と結合させた。抗 CD8 抗体についてはさらに N-hydroxysuccinimidobiotin（Sigma）と結合させたものも作製し た。

\section{5. フローサイトメトリー解析}

3カラーフローサイトメトリー解析を行う際 は, 分離した 細胞を FITC 標識抗 CD8 抗体之 APC 標識抗 CD4 抗体で染色した。4 カラーフロ 一サイトメトリ一解析の場合は, 細胞を図に示し た FITC 標識抗体, ビオチン標識抗 CD8 抗体と 反応させた後, $\mathrm{APC}$ 標識抗 $\mathrm{CD} 4$ 抗体, テキサス レッド標識ストレプトアビジンと反応させた。さ らに Propidium iodide (PI, Sigma) を $1 \mu \mathrm{g} / \mathrm{m} l$ 加光て死細胞を染色し，解析時に除去した。解析 はアルゴンレーザーとダイレーザーを装着した FACStar plus flow cytometer (Becton Dickinson) で行った。

\section{6. 抗 CD3 抗体によるリンパ球のブラスト化}

抗 CD3 抗体を96穴プレートにコートし室温で 1 時間インキュベートした。MEM で 3 回洗浄 後, $10 \% \mathrm{FCS}$ 添加 RPMI 培地でブロッキングを 
1 時間行った。䛲蔵リンパ球，あるいは IIELを $2 \times 10^{5}$ 加えて 24 時間培善した。

培羕後りンパ球を抗 CD4, CD8 抗体で染色し, 同様に染色した新鮮分離細胞とフローサイトメト リーを用いて前方散乱光 (Forward angle Light Scatter：FSC) を調べることによって細胞の大 きさを比較した。

\section{III. 結 果}

\section{DP 細胞のパイエル板への出現}

異なった週例のマウスのパイェル板について $\mathrm{CD} 4, \mathrm{CD} 8, \mathrm{PI}$ によ 3 カラーフローサイトィト リーを行ったところ, 表 1 のよらに DP 細胞が生 後 2 週から 3 週のマウスのパイエル板に認められ た。同じ時期のマウスの脾臟には，このような細 胞は存在しなかった。また，DP 細胞が認められ た日から 1 週後に同じ母親から同じ日に生まれた マウスを調べてみると，上記のような DP 細胞は すでに認められず，きわめて一過性に出現するも のであることがわかった。

異なった系のさまざまな週龄のマウスを調べた が， DP 細胞はこの時期のマウスであっても必ず しも認められず，出現がきわめて一時的かつ不規 則であることがわかった。

\section{DP iIEL の表面抗原}

パイェル板の T細胞は胸管を経て小腸上皮間な ど消化管に分布することが知られている。パイェ ル板のT細胞が IIELの前駆細胞を含むことか ら，マウス小腸から iIEL を分離して調べたとこ

表 1 同じ母視から同じ日に生まれた C3H マウス のパイエル板の細胞を分離し FITC 標識抗 CD8 抗体, APC 標識抗 CD8 抗体で染色し DP 細胞 の比を計算した。死細胞はPI で染色し解析に 含めなかった

\begin{tabular}{c|rc}
\hline \multicolumn{3}{c}{ DP cells in the Peyer's patches (\%) } \\
\hline Weeks after birth & Experiment 1 & Experiment 2 \\
\hline 2 weeks & $0.40 \%$ & $1.96 \%$ \\
3 weeks & $11.67 \%$ & $0.38 \%$ \\
4 weeks & $0.15 \%$ & $0.4 \%$ \\
\hline
\end{tabular}

ろ，パイェル板の所見とは全く異なり，成熟マウ スの小腸上皮間には常に $3 \sim 10 \%$ DP 細胞が認 められた。

4 カラーフローサイトメトリーでこの DP 細胞 のもつ他の表面抗原を調べたところ, 図 1 に示 すように $97.3 \%$ で Thy-1+, $99.2 \%$ で $\mathrm{CD}^{+}$, $\mathrm{TcR} \alpha \beta+$ であった。胸腺に拈ける未熟な $\mathrm{CD} 4+8^{+}$ 細胞は，TcRを弱くしか発現していないが，小 腸上皮間の $\mathrm{DP}$ 細胞は CD3 拈よび $\mathrm{T} c \mathrm{R} \alpha \beta$ を強 く発現していることが注目された。この事実は iIEL 中の DP 細胞が成熟したT細胞であると思 われた。また，上皮間リンパ球の $\mathrm{CD} 4-8+$ 細胞 のらち，98\%はCD3+であるが，その60\%のみが $\mathrm{TcR} \alpha \beta^{+}, \mathrm{Thy}-1^{+}$であり，他は $\gamma \delta \mathrm{T}$ 細胞である ことが示された。

\section{3. 無菌マウスの IIEL の性状}

マウスは生後 2 週頃から固形食を食べ始める。 このころ, 腸内環境では, 食物抗原の侵入や常在 菌の定着など変化が著しい11)。

そこで, SPF マウスと無菌マウスの iIELを用 いて各サブセットの総細胞数を調べてみると，図 2 に示すように無菌マウスでは IIELの細胞数は 大きく減少していた。そのなかでも DP IIEL は 全く認められず，DP iIEL は腸内環境の変化に 伴って反応性に誘導されてくることが明らかとな った。

無菌マウスに拈いても iIEL 中に $\mathrm{CD} 4+$ 細胞, CD4-8一細胞， CD8+ 細胞は SPF マウスと同様 に認められた（図2）。4カラーフローサイトメ トリーで無菌マゥスの CD4-8+ iIEL の TcR を 調べてみると $\mathrm{T} c \mathrm{R} \alpha \beta+$ 細胞は汪とんど存在 せず $\mathrm{CD} 3+$ は存在したことから, CD4-8+ TcR $\gamma \delta \mathrm{T}$ 細 胞は無菌マゥスにも存在することが認められた。 一方, $\mathrm{CD} 4-8^{+} \mathrm{T} \mathrm{CR} \alpha \beta$ 細胞は SPF 条件下で誘導 されてくることが明らかとなった。

\section{4. 老化が DP IIEL に与える影響}

上記のように DP iIEL が環境に強く影響を受 けたことから，さらに老化による影響について検 索した。老化マウスとしてはB10.A マウス执よ び $\mathrm{A} / \mathrm{J}$ マウスの 24 カ月齢を過ぎたマウスを用い 

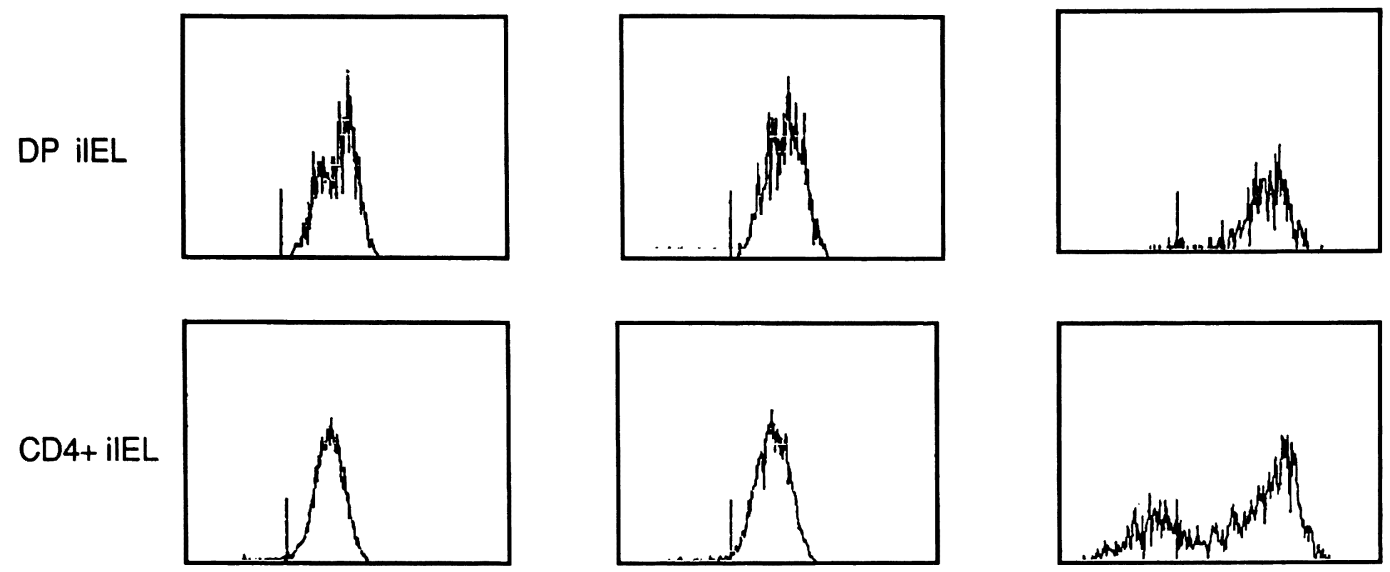

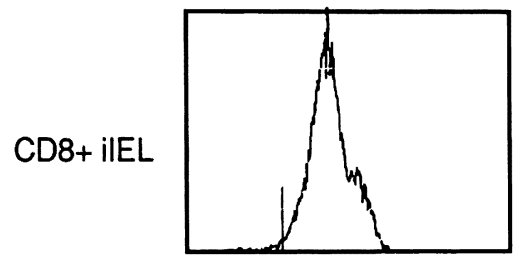

CD3

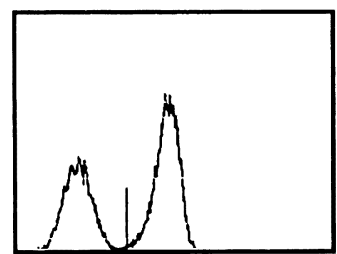

TcR $\alpha \beta$

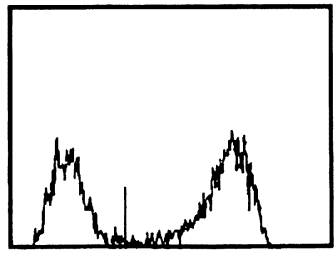

Thy 1

図 $1 \mathrm{C} 3 \mathrm{H}$ マウスの $\mathrm{IIEL}$ を分離し APC 標識した抗 CD4 抗体, ビオチン標識した抗 CD8 抗体と反応させ た後, アビジンテキサスレッドで染色し, FITC 標識した抗 CD3, TcR, Thy 1 抗体のいずれかで染色 した。死細胞はPIで染色し解析に含めなかった。眓はCD4, DP, CD8 iIEL の各分画に表現されたCD3, TcR, Thy 1 をヒストグラムで示した。図中の縦線は陰性対照の䖝光強度の最大值を示し, 縦線より右 は染色した抗原について陽性, 左は陰性である

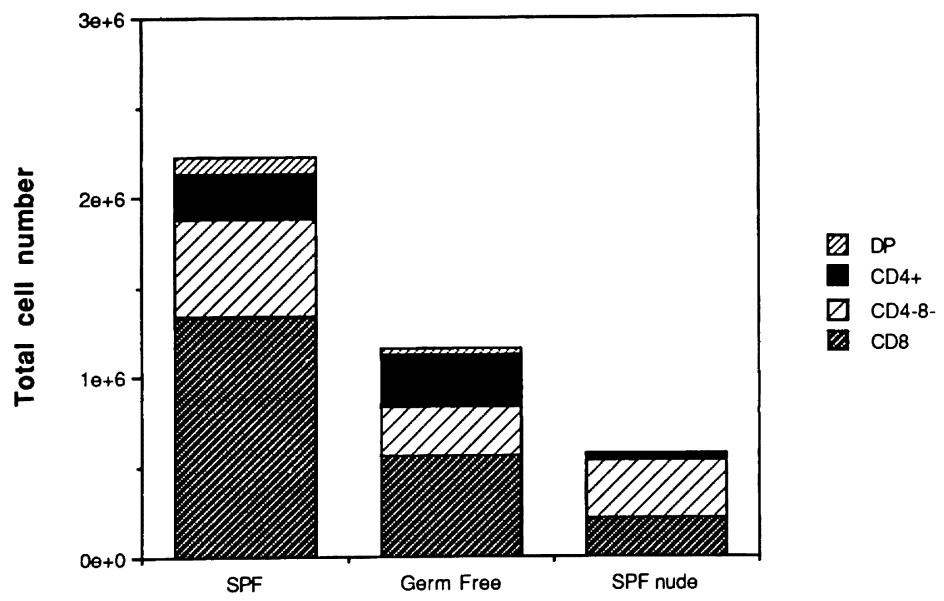

図 $2 \mathrm{BALB} / \mathrm{c}$ の SPF, Germ Free, SPF nude マウスの iIEL を分離し APC 標識抗 CD4, FITC 標識抗 CD8 で染色して CD4, DP, CD4-8-, CD8 各サプセット比を求め, iIEL の総細胞数 と乗じて各サブセットの総細胞数を求めた。死細胞は PI で染色し解析に含めなかった

図は 5 回の実験の平均を示す 


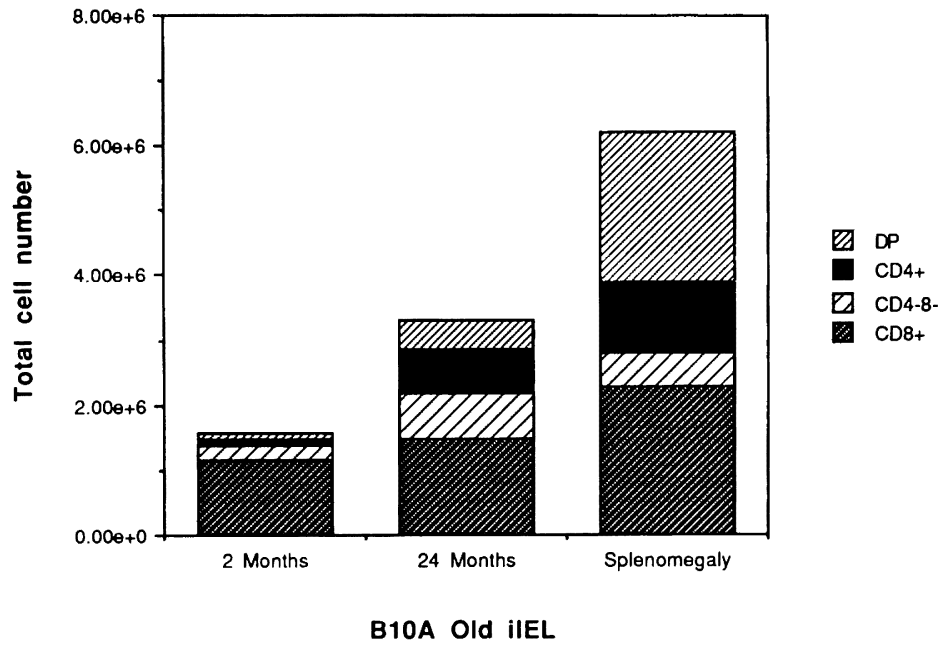

図 3 B 10. A 2 力月齿令と24力月龄マウスの iIEL を分離し, 各個体ごと に PE 標識抗 CD4, FITC 標識抗 CD8 で染色して CD4, DP, CD4-8-, CD8 各サブセット比を求め, iIEL の総細胞数と乗じて各サブセッ トの総細胞数を求めた

図は各個体の平均值を示す。老化マウス中で脾腫を伴う個体があ り右に別記した

た。

図 3 に示すようにB10. A 老化マウスでは IIEL の総細胞数は約 2 倍に增加していた。老化マウス の脾蔵ではすでに 報告されているように ${ }^{12)} \mathrm{CD} 8$ 細胞の減少が認められたが（図 4 右下）。一方, 図 4 右上に示すように同じマウスに拈いて DP iIEL が逆に増加しているのが注目された。老化 マウスでは胸腺細胞数は減少しており, 胸腺から のT細胞の供給が高まっているとは考光られない ので，小腸上皮に括ける DP iIEL の拡大は消化 管局所で起こるものと思われた。

老化マウスのなかには SPF 条件下でも非腫瘍 性の脾腫がしばしば認められるが，このような動 物では, 図3のように DP iIEL が顕著に増加し ていた。脾腫の原因は明らかではないが B 10. A マウスに限らず A/J マウスでも脾腫が認められ, このよらなマウスでは図 5 右上のよらに DP iIEL の顕著な増加が必ずみられた。このような老化マ ウスでは図 5 左上のようにパイエル板にも DP 細 胞が認められ，局所において DP IIEL が顕著に 増加する際には，パイエル板にも DP 細胞が現れ
ることが明らかとなった。

\section{DP IIEL の分化}

通常胸腺にしか認められない下細胞が消化管上 皮間に存在したことから，DP 細胞は消化管で分 化した細胞であることが推定された。そこで胸腺 を欠くヌードマウスの上皮間リンパ球を調べた。 ヌードマウスは末梢に T細胞はほとんど認められ ないが，iIELを調べると図 2 に示すように CD8+ iIEL や CD4-8- iIEL は存在し, これらのT細 胞サブセットが胸腺外分化を遂げたものであるこ とが示㖫される。これに反し、ヌードマウスには $\mathrm{DP}$ 細胞は認められなかった。このことから SPF マウスの小腸上皮間に認められる DP 細胞は 胸腺依存性の分化を遂げたことが明らかとなっ た。

また，胸腺内分化の過程で自己に反応する $\mathrm{T}$ 細 胞は消去されるといら，いわゆるネガティブセレ クションが拈こることが知られている。マイナー 組織適合抗原の一つである Mls-2aをもっている マウスでは, $V \beta 3$ を発現した $\mathrm{T}$ 細胞は胸腺内で 消去されることが知られている8)。こうした事実 


\section{B10.A mouse}

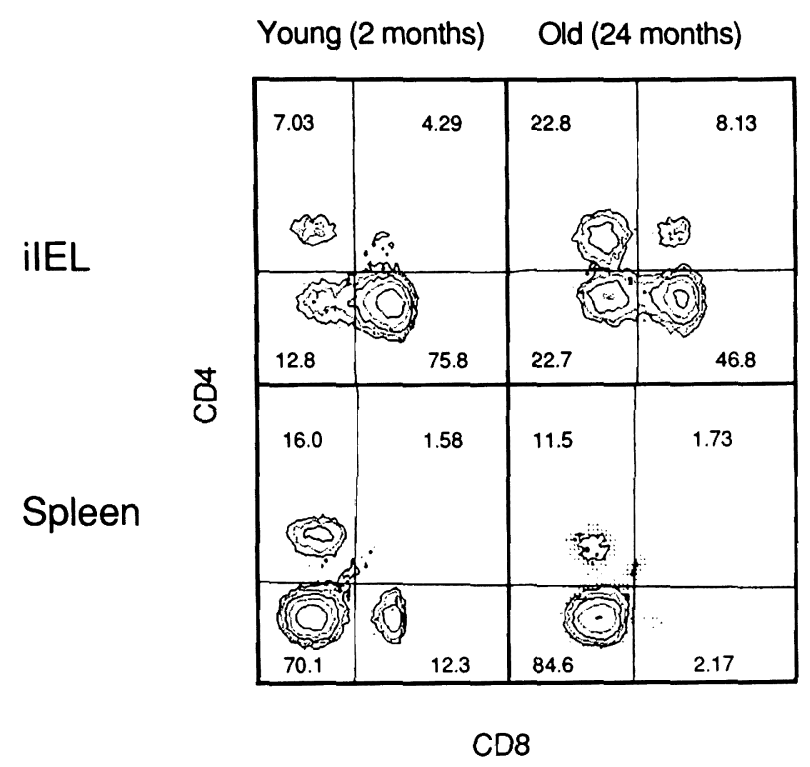

図 4 B10.A の 2 力月觜令と 24 力月龄マウスの iIEL, 脾臓細胞 を分離し，各個体ごとに PE 標識抗 CD4, FITC 標識抗 CD8 で染色した。図中数字は各分画の\%を示す

を基に、この DP iIELがネガティブセレクション を受けているか否かを検討した。異なった MIs 抗 原を遺伝的にもつ系統のマウスを用いて TcRV $\beta_{3}$ の DP 細胞中にしめる割合を調べたところ, Mls-2a である C $3 \mathrm{H}$ マウスでは図6右のように $\mathrm{V} \beta_{3}$ の 発現が消去されており，Mls一2 $\mathrm{B} 10 \mathrm{BR}$ マゥスでは図 6 左のように $\mathrm{V} \beta_{3}$ の発現が 認められた。 Mls-2a とは無関係の V 36 はこれら 両方のマウスの DP iIEL で消去されていなかっ た。このことから DP 細胞が胸腺内でネガティブ セレクションを経てきていることが明らかとなっ た。

\section{DP IIEL の機能}

成熟 $\mathrm{T}$ 細胞は，抗 CD3 抗体による刺激でブラ スト化し増殖することが知られている。その際に さまざまなインターロイキンを産生してT細胞の 機能を発現する。ilEL および脾臓細胞を抗 CD3 抗体で刺激し，反応した細胞のサイズを測定し た。それを刺激していない新鮮分離 IIEL と比較
したところ，図７に示したように破線で示した 新鮮分離細胞に比べて CD3 刺激細胞は右方移動 し，そのサイズを増していた。脾臓細胞と同様に iIEL もサイズが増加することがわかった。この 際 DP iIEL でも CD4+8-, CD4-8+ iIEL と同様 に細胞のサイズの増加が認められた（図７）。

\section{IV. 考察}

消化管上皮間には，IEL と呼ばれる特改のある T細胞が分布している。そのらちでも DP IIEL は 胸腺にしか存在しない $\mathrm{CD} 4+\mathrm{CD} 8+$ の phenotype をもち，その由来や意義が注目されている。本研 究の結果, DP iIEL は CD3 と T CR $\alpha \beta$ を表現し た成熟 $\mathrm{T}$ 細胞であることがわかった。この細胞は SPF 条件下では認められるが無菌マウスやヌー ドマウスには認められなかった。老化マウスでは 新たに増加していることがわかった。

$\mathrm{DP}$ 細胞は $2 \sim 3$ 週跘のマウスや脾腫を伴う老 化マウスのパイエル板にきわめて一時的に認めら 


\section{A/J Old Mouse (24 months)}

Peyer's patches

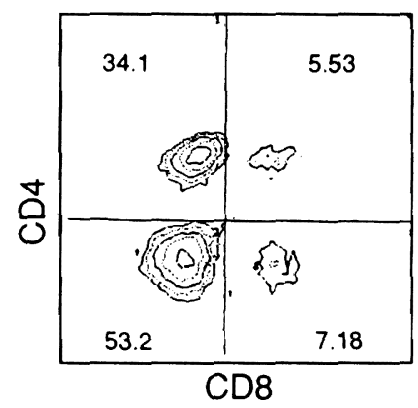

iIEL

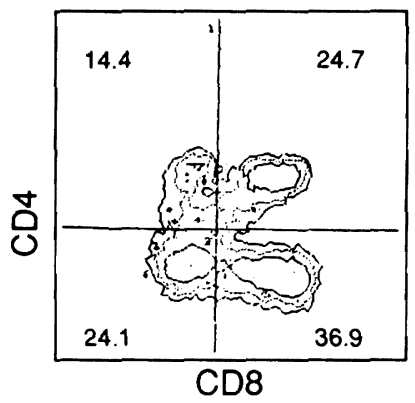

Splenomegaly

Peyer's patches

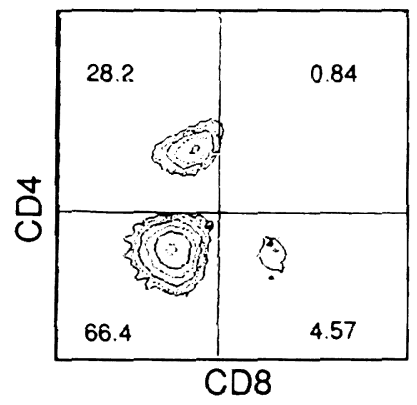

iIEL

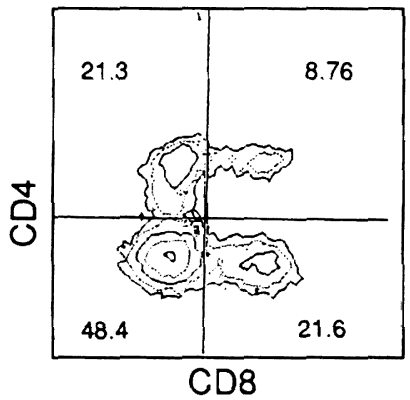

\section{Normal}

図 524 力月齒で脾腫を伴う $\mathrm{A} / \mathrm{J}$ マウスと伴わない $\mathrm{A} / \mathrm{J}$ マウスの $\mathrm{iIEL，パ}$ イェル板細胞を分離し，各個体ごとに PE 標識抗 CD4, FITC 標諹抗 CD8 で染色した。図中数字は各分画の\%を示す

れたが，他のリンパ組織には認められなかった。

このことから胸腺から供給された $\mathrm{T}$ 細胞の一部が パイル板にいたりやがて DP iIEL として小腸 に分布する過程が示唆された。DP iIEL は Mls 抗原によるネガティブセレクションを受けてい た。

胸腺内では未成染の CD4-8一細胞および $\mathrm{CD}^{-}$8+ $^{+}$細胞は DP 胸腺細胞となり，成熟した のち $\mathrm{CD}^{+}{ }^{+}$あるいは $\mathrm{CD} 8^{+}$細胞へと分化してゆ くことが知られている。したがって DP 細胞は成
熟したT細胞の未熟な 前駆細胞と考兄られてい る。もしも小腸で胸腺外分化が起こるのであれ ば, この DP iIEL は未熟なT細胞で CD4 あるい は CD8 細胞へと分化する可能性が考兄られた。 しかし CD3 およびTCRを強く発現していること から，この細胞は形態的に成熟した T 細胞である ことが明らかとなった。また，CD3を介した刺 激によりブラスト化が認められたことから DP 細 胞は機能的にも成熟したT細胞であることが確認 された。 


\section{DP ilEL}
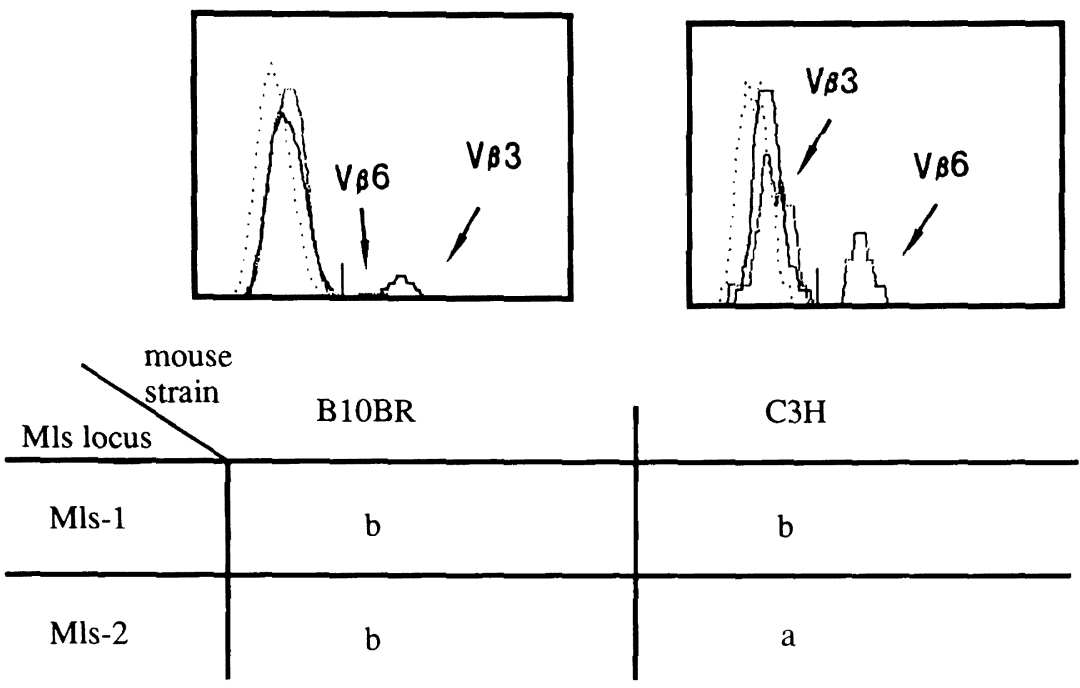

図 $6 \mathrm{~B} 10 \mathrm{BR}, \mathrm{C} 3 \mathrm{H}$ マウスの $\mathrm{iIEL}$ を分離し APC 標識した抗 CD4 抗体，ビオチン鲸 識した抗 CD8 抗体と反応させた後，アビジンテキサスレッドで染色し，FITC 標 識した抗 TcRV $\beta 3, V \beta 6$ 抗体のいずれかで染色した。死細胞はPI で染色して解 析に含めなかった。図はDP IIEL に表現された TcRV $\beta 3, V \beta 6$ をヒストグラムで 示した。図中の破線は陰性対照を示す。図中の縱線は陰性対照の篮光強度の最大 值を示し，縦線より右は染色した抗原に対して陽性である

図2で明らかなようにヌードマウスには CD8 iIEL, CD4-8- iIEL が存在し, CD4 iIEL がわず かに存在した。これらは消化管で胸腺外分化した ことを示唆する。しかし DP iIEL が認められな いことから，DP 細胞は胸腺依存性の分化を遂げ ているものと思われた。

ネガティブセレクションは，自己反応性のT細 胞による自己の破壊を防ぐための主要なメカニズ ムであり，マウスに拈いては自己の Mls 抗原に 反応性の V $\beta$ 陽性細胞が消去されることが報告さ れている ${ }^{8)}$ 。安部らは $\mathrm{V} \beta 3$ 陽性 $\mathrm{T}$ 細胞クローンを 調べた結果, V $\beta 3$ 陽性の T 細胞が Mls-2a の抗原 提示細胞と反応することを見い出した ${ }^{13)}$ 。をた， Pullen らは Mls-2a のマウスではV V $\beta 3$ 陽性の T 細胞が消去されることを報告した ${ }^{8)}$ 。これらがネ ガティブセレクションの例である。また，このネ ガティブセレクションはT細胞が DP の段階で起
こることが報告されている14)。

このことから, DP iIEL がネガティブセレク ションを受けてから消化管に分布したのか，それ とも受けていない DP 細胞が消化管に分布したの かを調べるために，Mls-2a である C $3 \mathrm{H}$ マウスの $\mathrm{V} \beta 3$ 陽性細胞の割合を調べたところ DP iIEL 中 にV $\mathrm{V} 3$ 陽性細胞は存在せず, DP IIEL がネガテ ィブセレクションを経てきていることが明らかと なった。

iIELのらち胸腺由来のものはパイエル板で抗 原刺激を受けそこを経由して小腸上皮間へ分布 し，その一方で胸腺外分化を遂げるものはパイエ ル板を経ず直接上皮間で分化することが報告され

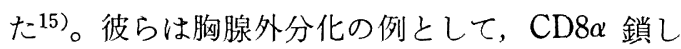
かもたないCD8 iIELはネガティブセレクション を受けていないT細胞が多いことをあげ，このサ ブセットが胸腺外分化を遂げるとしている。 DP 
DP
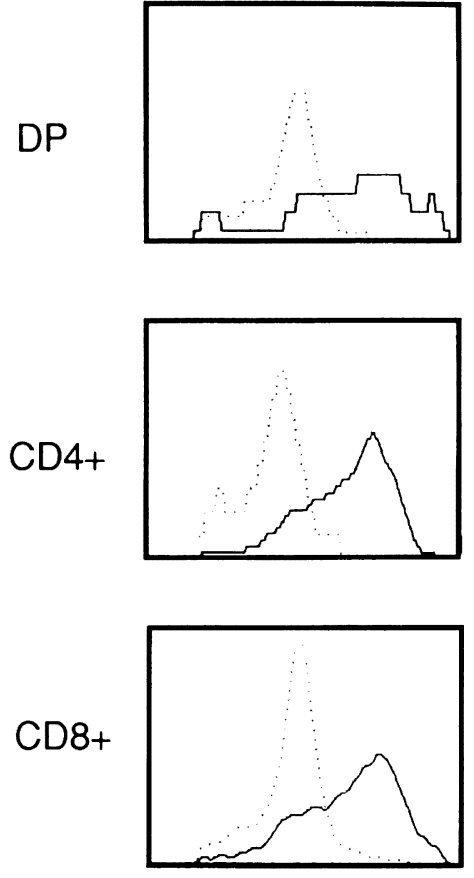

iIEL
C D 3 刺激細胞

新鮮分離細胞
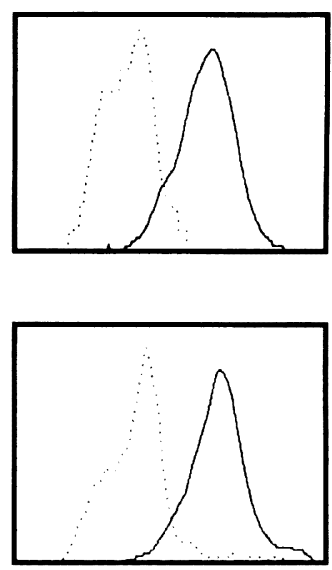

Spleen

\section{Forward Scatter}

図 7 iIEL，脾臟細胞を分離後抗 CD3 抗体で刺激し24時間培養し た後 FITC 標識抗 CD8, APC 標識抗 CD4 抗体で染色した

図は培善後の CD4, DP, CD8 各サブセットの細胞の大きさを 新鮮分離細胞との比較を Forward Scatter のヒストグラムで示 した。死細胞はPIで染色し解析に含めなかった

iIEL の CD8 も多くは $\alpha$ 鎖のみであることが報告 されており16)，これが胸腺外分化の指標であるな らば DP iIEL が胸腺外分化を遂げた可能性を示 唆する。しかし, 図6のように DP iIEL はネガ ティブセレクションを受けていた。 $2 \sim 3$ 週齢の マウス, 脾腫を起こした老化マウスで DP 細胞が パイエル板に認められたことは胸腺由来の細胞と 類似する。ヌードマウスの結果と合わせ, DP IIEL は胸腺由来であることが明らかとなった。

マウスは生後 2 週頃から固形食を食べ始め, 八 イェル板は急激に大きさを增す。食物抗原の侵入 に加光常在細菌灇も変化するなど11)消化管の微小 環境も大きく変化する。奏際に解剖するときに胃
の内容物をみると、ミルクと思われる白い内容物 が認められる時期から固形食と思われる緑色の内 容物へと変わる時期にパイェル板は肉眼的にかな り大きくなっていた。このころのマウスのパイエ ル板に DP 細胞が認められたことは，この細胞が 腸内環境の变化に対応して誘導されてきたと考え られる。無菌マウスにほとんど認められなかった ことは, DP 細胞が特に腸内細菌の変化に伴い誘 導されてきたことを示唆している。

老化マウスの脾臓で CD8 細胞の割合が減少し ていたのが認められたが，脾蔵では減少している にもかかわらず，同じマウスの DP iIEL は減少 せず，増加していた。胸腺細胞は加㱓とともに減 


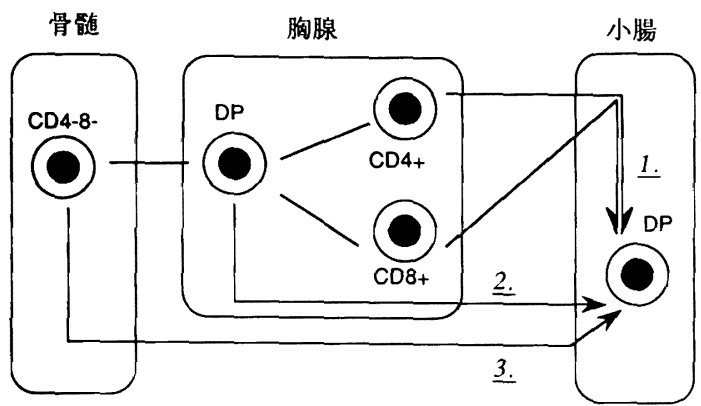

図 8 DP ilEL の想定しうる分化経路

1. 胸腺で CD4 あるいは CD8 細胞へと分化した 後に消化管に移り，いずれか一方(CD4 またはCD8) を獲得し DP となる経路

2. 胸線の DP 細胞がそのまま小腸へと分存する 経路

3. 骨能道細胞が直接小腸で分化し DP 細肥になる という経路

少し，胸腺から末梢への T 細胞の供給能が DP IIEL に関してのみ充進することは考劣にくいの で，DP iIEL は胸腺を経た後に腸管局所で增殖す ると思われる。 $2 \sim 3$ 週榆のマウス, 脾腫を起こ した老化マウスで DP 細胞がパイエル板に認めら れ，脾蔵やリンパ節に認められないことからも， DP 細胞は腸管局所で增殖することが示唆され た。

DP 細胞が成熟した機能的なT細胞であること から次の上らな分化経路を想定した（図 8)。1.

胸腺で CD4 あるいは CD8 細胞となった後に消化 管に移り，いずれか一方（CD8 またはCD4）を 獲得し DP iIEL となる経路。2.胸腺の DP 細胞 がそのまま小腸へと分布するという経路。3.骨髄 細胞がそのまま小腸で分化し DP 細胞になるとい 弓経路。

DP iIEL がスードマウスに存在せず（図2）， ネガティブセレクションを受けていた（図 6 ）こ とは，DP 細胞が胸腺依存性であるといら1また は2 の可能性が考えられる。Mosley らは胸腺切 除した骨髄キ人ラを用いて DP iIEL が胸腺外分 化を遂げることを報告しているが17)，これは上述 の 3 の経路を示唆するものである。スードマウス の IIEL には TcRrò 細胞は存在しているのに対

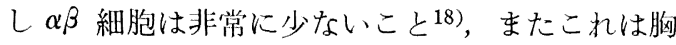
腺切除したキメラマウスでも同様であること ${ }^{19}$ が 報告されている。DP 細胞がすべて $\alpha \beta T$ 細胞であ り，少なくともその大部分は胸腺依存性であるこ とは， $\alpha \beta$ iIEL が胸腺依存性であるという上記の 報告からも間接的に支持される。胸腺依存性之考 えられる今回の実験結果之胸腺外分化を主張する Mosley らの報告の違いはまだ完全に説明できな い。一つの可能性としては, 図 4 のようにヌード マウスの iIEL にはわずかではあるが CD4, CD8 細胞が存在するので, 彼らの報告した胸腺切除マ ウスの DP IIEL が1の経路を経た細胞であるこ とが考党られる。つまりわずかな胸腺外分化した CD4, CD8 細胞がなんらかの刺激でもら一方の分 子を獲得するとともに增殖して DP iIEL になる ことである。

Paliard らは, 林梢血の CD4 細胞を IL-4 存在 下で培養し細胞傷害性をもつ DP 細胞を得てい $ろ^{20)}$ 。 Mingari らは胸腺の CD4-8- 細胞を培 養し，刺激を繰り返すことによって細胞傷害性を もつ CD8+ TcR rò 細胞を得ている21)。また，獲 得された CD8 分子は $\alpha$ 鎖のみの CD8 である。こ れらのことは, 上記 1 の経路を示咬する。つま り，胸腺を経た CD4 細胞が腸管で CD8 分子を獲 得し, DP 細胞として分布していると考えられ る。

腸管における CD8 分子の獲得は, Bonneville らの報告からも支持される22)。彼らは IIELの $\gamma \delta \mathrm{TcR}$ とは異なったタイプの $\gamma \partial \mathrm{T} \mathrm{T} \mathrm{R}$ をいれた トランスジェニックマウスを作成し，その iIEL を検索したところ， スの iIEL は CD8 の発現が弱かったとしている。 CD8 分子が腸管局所で増殖する際に獲得する分 子であるならば，胸腺外分化する iIEL が $\alpha$ 鎖の みの CD8 細胞であることや, DP 細胞が CD8 細 胞の減少した老化マウスでも減少せず，腸管局所 で增殖することと矛盾しない。

同じく 1 の経路として CD8 細胞が CD4 分子を 得る可能性も考古られる。Paolo Lusso らは, ヒ ト CD8 細胞を human herpes virus 6 に感染さ 
せるとCD4 分子を発現することを見い出した ${ }^{23) 。 ~}$ このことは, 成熟 CD8 細胞が DP 細胞となる可 能性を示唆している。

抗 CD3 抗体の刺激によってブラスト化するこ とから，DP IIELは成熟した機能的なリンバ球で あることが明らかとなったが，腸管に捛けるDP 細胞の果た寸役割については現在のところ明らか ではない。 IIEL には細胞傷害性をもつものが多 く, 感染などで傷害をらけた上皮細胞を取り除く 役割を担らと考光られる24)。この細胞傷害活性は 無菌マウスには認められないことが報告されてい る25)。DP 細胞も無菌マウスに認めらず，この細 胞傷害活性をもつ可能性が示唆されるが確認は行 われていない。

細胞傷害性をもつ iIEL が CD1 分子を認識す ることが報告された26)。CD1 分子はマウスやヒ トの腸管上皮の他, 歯肉上皮にも発現されている ことが知られている27)。CD1 分子の発現量は IL1 によって上昇することが報告されて抢り27)，感 染や炎症に伴う CD1 発現量の増加とそれに伴う iIEL の活性化が示㖫される。感染, 炎症により Class I, Class II の発現も上昇すること ${ }^{28)}, \mathrm{CD} 4$, CD8 分子はそれぞれ Class II, Class I に結合する ことが知られている29,30)。DP 細胞の腸管局所に おける增加，無菌、ウスに存在しないことから， 細菌，炎症などの局所環境の変化による CD1, Class I, Class II などの変化が DP 細胞の活性化, 増殖に大きな影響を与えているであろら。

ヒト末梢血では，わずかに DP 細胞が存在する が31)，霜肉上皮に招ける局在は確認されていな い。畨周疾患のような消化管局所の炎症性疾患を 考察するら壳で, マウスの DP iIEL のように, 胸腺で分化しているにもかかわらず局所環境に対 応して増加する T細胞が存在することは興味深 い。特に，老化のT細胞サブセットに与光る影響 が消化管局所と他のリンパ装置で異なることは, 加路の雨周疾患に与兄る影響を免疫学的見地から 調べる際に，単純に全身免疫系を調べるだけでは 不十分であることを意味する。本研究のモデル は，マウスの小腸のリンパ球であったが，今後こ
れらの知見を基に歯周組織をモデルとした検索が 重要であると思われる。

\section{V. 結論}

1. $\mathrm{DP}$ 細胞が， $2 \sim 3$ 週粭のマウスのパイェ 儿板に一時的に認められた。また，老化マウス， 特に脾腫を伴う老化マウスで DP 細胞は増加し, 局所での増殖が示唆された。

2. DP 細胞は SPF マゥスの小腸上皮間に認 められるが，無菌マウスには認められなかった。

3. DP 細胞はヌードマウスには認められず, またネガティブセレクションを受けて招り胸腺依 存性の T 細胞サブセットであると思われた。

\section{謝辞}

稿を終えるにあたり，罳篤なるご指導ならびにご校 閱を賜りました石川烈教授に深甚なる感謝の意を表し ますとともに，終始愁切丁寧なご教授とご校閲をいた だきました東京大学免疫学教室 多田富雄教授に深く 感謝いたします。

また，丁寧なご助言，ご教示をいただきました東京 大学免疫学教室 浅野喜博助教授, 佐野公仁夫博士に 心から感謝の意を表します。

さらにさまざまなご援助，ご協力をいただきました 理化学研究所池郁夫博士, 水谷武夫博士, 動物実験 に際しご協力いただきました横池妙子さん，文献の収 集, 整理にご助言をいただきました山口葉子さんに厚 く打礼申しあげます。

最後に，喛かいご援助をいただきました東京医科歯 科大学碀科保存学第 2 講座, 東京大学免疫学教室の方 々に深く感謝いたします。

\section{文献}

1）長沢敏行, 佐野公仁夫, 多田富雄 : 免疫細胞分 化の場としての消化管. 細胞工学 9 ：795801, 1990.

2) Mosley, R. L., Styre, D. and Klein, J. R. : CD4 ${ }^{+}$ $\mathrm{CD}^{+}$murine intestinal intra epithelial lymphocytes. Int. Immunol. 2:361-365, 1990.

3) Taguchi, T., Mcghee, J. R., Coffman, R. L., Beagley, K. W., Eldridge, K., Takaku, K. and Kiyono, H. : Analysis of Th1 and Th2 cells in murine gut-associated tissues : frequency of $\mathrm{CD}^{+}$and $\mathrm{CD}^{+} \mathrm{T}$ cells which secrete IFN $r$ and 
IL5. J. Immunol. $145: 68,1990$.

4) Ledbetter, J. A. and Herzenberg, L. A. : Xenogenic monoclonal antibodies to mouse lymphoid differentiation antigens. Immunol. Rev. $47: 63,1979$.

5) Leo, O., Foo, M., Sachs, D. H., Samelson, L. E. and Bluestone, J. A. : Identification of a monoclonal antibody specific for a murine T3 polypeptide. Proc. Natl. Acad. Sci. USA 84 : $1374,1987$.

6) Dialynas, D. P., Quan, Z. S., Wall, K. A., Pierres, M. and Fitch, F. W. : Characterization of murine surface molecule, designated L3T4, identified by monoclonal antibody GK1. 5 : similarity of L3T4 to the human Leu3/T4 molecules. J. Immunol. $131: 2445,1983$.

7) Kubo, R. T., Born, W., Kappler, J. W., Marrack, P. and Pigeon, M. : Characterization of a monoclonal antibody which detects all murine $\alpha \beta$ T-cell receptors. J. Immunol. $142: 2736$, 1989.

8) Pullen, A. M., Marrack, P. and Kappler, J. W. : The $T$-cell repertoire is heavily influenced by tolerance to polymorphic self-antigens. Nature 335 : 796-801, 1988.

9) Acha-obea, H., Zinkernagel, R. M. and Hengartner, H. : Cytotoxic $T$ cell clone-specific monoclonal antibodies used to select clonotypic antigen-specific cytotoxic $\mathrm{T}$ cells. Eur. J. Immunol. $15: 31,1985$.

10) Hardy, R. R. : Purification and coupling of fluorescent proteins for use in flow cytometry. In Weir, D. M., Herzenberg, L. A., Blackwell, C. C. and Herzenberg, L. A., eds : Handbook of experimental Immunology, 4th edn, Ch. 31, p. 1. Blackwell Scientific, Edinburg.

11) Koopman, J. P., Stadhouders, A. M. and H. de Boer: De Darmflora van de muis Tijdschr. Diergeneek. $106: 748-756,1981$.

12) Komuro, T., Sano, K., Asano, Y. and Tada, T. : Analysis of age-rerated degeneracy of $T$ cell repetoire : Localized functional failure in $\mathrm{CD}^{+} \mathrm{T}$ cells Scand. J. Immunol. $32: 545$, 1990.

13) Abe, R., Vacchio, M. S., Barbara Fox and Hodes, R. J. : Prefarential expression of the $T$-cell receptor $V \beta 3$ gene by $M l s$ reactive $T$ cells. Nature $335: 827-830,1988$.

14) MacDonald, H. R., Hengartner, H. and Pedrazzini, T. : Intrathymic deletion of self-reactive cells prevented by neotal anti-CD4 antibody treatment. Nature 335: 174-176, 1988.

15) Rocha, B., Vassalli, P. and Guy-Grand, D. :
The $\mathrm{V} \beta$ repertoire of mouse gut homodimetric $\alpha \mathrm{CD}^{+}$intraepithelial $\mathrm{T}$ cell receptor $\alpha / \beta^{+}$ lymphocytes reveals a major extrathymic pathway of $\mathrm{T}$ cell differentiation. J. Exp. Med. $173:$ 483-486, 1991.

16) Lefrancois, L. : Phenotypic complexity of intraepithelial lymphocyted of the small intestine. J. Immunol. $147:$ 1746-1751, 1991.

17) Mosley, R. L., Styre, D. and Klein, J. R. : Differentiation and functional maturation of bone marrow derived intestinal $\mathrm{T}$ cells expressing membrane $\mathrm{T}$ cell recepter in athymic radiation chimeras. J. Immunol. 145 : 13691375, 1990.

18) Bandeira, A., Mota-Santos, T., Itohara, S., et. al. : Localization of $\gamma / \delta \mathrm{T}$ cells to the intestinal epithelium is independent of nomal microbial colonization. J. Exp. Med. 172: 239-244, 1990.

19) Bandeira, A., Itohara, S. and Bonneville, M. : Extrathymic origin of intestinal intraepithelial lymphocytes bearing $T$-cell antigen receptor $\gamma \delta$. Proc. Natl. Acad. Sci. USA $88: 43-47$, 1991.

20) Paliard, X., Malefijt, R. W., Vries, J. E., et. al. : Interleukin-4 mediates CD8 induction on human $\mathrm{CD} 4^{+} \mathrm{T}$-cell clones Nature 335 : 642$644,1988$.

21) Mingari, M. C., Varese, P., Bottino, C., et. al. : Clonal analysis of $\mathrm{CD}^{-} \mathrm{CD}^{-}$human thymocytes expressing a $T$ cell receptor $\gamma / \delta$ chain. Direct evidence for the de novo expression of CD8 surface antigen and of cytolytic activity against tumor targets. Eur. J. Immunol. 18 : 1831-1834, 1988.

22) Bonneville, M., Itohara, S., Krecko, E., G., et.al. : Transgenic mice demonstrate that epithelial homing of $\gamma \boldsymbol{\partial} \mathrm{T}$ cells is determined by cell leneages independent of $\mathrm{T}$ cell receptor specificity. J. Exp. Med. 171 : 1018-1026, 1990.

23) Lusso, P., Maria, A., Malnati, M., et. al. : Induction of CD4 and susceptibility to HIV-1 infection in human $\mathrm{CD}^{+} \mathrm{T}$ lymphocytes by human herpesvirus 6 . Nature $349: 533-535$, 1991.

24) Janeway, C. A., Jr. : Frontiers of the immune system. Nature $333: 804-806,1988$.

25) Lefrancois, L. and Goodman, T. : In vivo modulation of cytolytic activity and Thy-1 expression of TCR $-\gamma \boldsymbol{\delta}^{+}$intraepithelial lymphocytes. Science $243: 1716-1718,1989$.

26) Balk, S. P., Ebert, E. C., Blumenthal, R. L., Mcdermott, F. V., Wucherpfenning, K. W., 
Landau, S. B. and Blumberg, R. S. : Oligoclonal expansion and $\mathrm{CD} 1$ recognition by human intestinal intraepithelial lymphocytes. Science $253: 1411-1415,1991$.

27) Walsh, L. J. and Seymour, G. J. : Interleukinl induces CD1 antigen expression on human gingival epithelial cells. J. Invest. Dermatol. $90: 13,1988$.

28) Barclay, A. N. and Mason, D. R. : Induction of Ia antigen in Rat epidermal cells and gut epithelium by immunological stimuli. J. Exp. Med. 156 : 1665, 1982.

29) Doyle, C. and Strominger, J. L. : Interaction between CD4 and class II MHC molecules mediayes cell adhesion. J. Exp. Med. 169 : $149,1989$.

30) Rosenstein, Y., Ratnofsky, S., Burakoff, S. and Herrmann, S. : Direct evidence for binding of CD8 to HLA class I antigen. J. Exp. med. $169: 149,1989$.

31) Blue, M-L., Daley, J. F., Levine, H., Craig, K. A. and Schlossman, S. F. : Coexpression of T4 and $\mathrm{T} 8$ on peripheral blood $\mathrm{T}$ cells demonstrated by two-color fluorescence flow cytometry. J. Immunol. $134: 2281,1985$. 